\title{
Necrotizing Fasciitis Caused by Photobacterium damselae: The First Case in Portugal
}

\author{
Fasceíte Necrotizante Causada por Photobacterium \\ damselae: O Primeiro Caso Descrito em Portugal
}

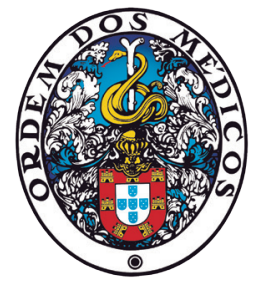

\author{
Diogo GUIMARÃES $\rrbracket^{1}$, Luís RIBEIRO ${ }^{1}$, Luís VIEIRA¹, Ruben COELHO² \\ Acta Med Port 2021 Sep;34(9):615-618 - https://doi.org/10.20344/amp.13032
}

\section{ABSTRACT}

Necrotizing fasciitis is a severe soft tissue infection with a high mortality rate and therefore requires emergent surgical treatment. Several microorganisms can cause this infection, Photobacterium damselae being one of them, with only eight cases previously published in the literature. We report the first ever case of necrotizing fasciitis, caused by this microorganism, in Portugal. In this case report the patient survived after several debridement procedures and reconstruction of the upper limb with acellular dermal matrix and skin graft. A brief review of the Photobacterium damselae soft tissue infection reports as well as the clinical presentation, diagnosis, pathophysiology and treatment of necrotizing fasciitis can also be found in this paper.

Keywords: Bacterial Infections; Fasciitis, Necrotizing; Hand Injuries; Photobacterium; Vibrio Infections

RESUMO

A fasceíte necrotizante é uma infeção grave que requer tratamento cirúrgico emergente, sendo responsável por uma elevada taxa de mortalidade. Existem vários microorganismos que podem ser responsáveis por este tipo de infecção, sendo o Photobacterium damselae um destes, com apenas oito casos descritos na literatura de fasceíte necrotizante por este agente, sendo o presente relato a primeira vez que é reportada uma infeção a este agente em Portugal. No presente caso o paciente sobreviveu após várias intervenções de desbridamento cirúrgico e reconstrução do membro superior com matriz dérmica acelular e enxertos de pele. Foi ainda realizada uma breve revisão de todos os relatos de infecção de tecidos moles por este agente, bem como um resumo da apresentação clínica, diagnóstico, fisiopatologia e tratamento da fasceíte necrotizante.

Palavras-chave: Fasceíte Necrotizante; Infecção por Vibrio; Infecções Bacterianas; Lesões da Mão; Photobacterium

\section{INTRODUCTION}

Necrotizing fasciitis is an infection involving the fascia and subcutaneous tissue, that spares the underlying tissues. Risk factors include immunosuppression, peripheral vascular disease, diabetes mellitus, chronic liver disease, and intravascular drug abuse.

Necrotizing fasciitis is often polymicrobial and group $A$ $\beta$-hemolytic Streptococcus is the most common group of microorganisms identified in microbial culture tests. ${ }^{1}$

The subspecies piscicida of the bacterium Photobacterium damselae ( $P$. damselae) is a well-studied fish pathogen, causing a zoonosis known as 'fish pasteurellosis', ${ }^{2}$ but infections in human are rare. We describe the first ever infection by $P$. damselae reported in Portugal and make a brief literature review of both necrotizing fasciitis and $P$. damselae infections.

\section{CASE DESCRIPTION}

A 65 year old man, fisherman, was transferred to the emergency department of our hospital because of pain and edema in his right hand. There was history of chronic renal failure dependent on blood dialysis through an arterialvenous fistula in the right arm. His regular medication was lisinopril, alprazolam and bicalutamide.

On admission the patient complained of progressively worse right hand edema and severe pain. He mentioned a history of trauma 12 hours earlier in a fish cleaning table. During our physical examination he presented with right hand edema, reduced movement amplitude and strength of the wrist and all the fingers. The fingers had good perfusion and no sensitive deficits. There was a small wound in the dorsum of the hand (Fig. 1). The blood tests at admission had a white blood cell (WBC) count of $10770 \times 10^{\wedge}$ 9/L with $86 \%$ neutrophils; and a $C$ reactive protein (CRP) of 31.1 $\mathrm{mg} / \mathrm{L}$. Swab, skin biopsy and blood cultures were collected. About two hours after admission, the patient was taken to the operating room and fasciotomies of the hand and wrist were performed. Empiric antibacterial therapy with amoxicillin/clavulanic acid and metronidazole was initiated.

About 15 hours after admission, skin necrosis in the dorsum of the right hand and progression of edema to the forearm was observed. The patient developed septic shock and underwent emergent debridement (Fig. 2). A preliminary identification of $P$. damselae was possible after 48 hours and adequate antibiotic therapy with ceftriaxone and doxicicline was initiated.

On day 10 and 17 after admission, surgical debridement procedures were carried out. From the $17^{\text {th }}$ day onwards, a regimen of negative pressure therapy was started. The antibiotic therapy was stopped at day 21. At day 25 an acellular dermal matrix (ADM) was applied (Fig. 3). Four weeks later,

1. Serviço de Cirurgia Plástica Reconstrutiva e Estética. Centro Hospitalar Universitário Lisboa Central. Lisboa. Portugal.

2. Serviço de Cirurgia Plástica Reconstrutiva e Estética. Centro Hospitalar Universitário de São João. Lisboa. Portugal.

$\triangle$ Autor correspondente: Diogo Guimarães. diogoandradeguimaraes@gmail.com

Recebido: 28 de outubro de 2019 - Aceite: 10 de janeiro de 2020 - First published: 24 de agosto de 2020 - Online issue published: 01 de setembro de 2021 Copyright $\odot$ Ordem dos Médicos 2021 


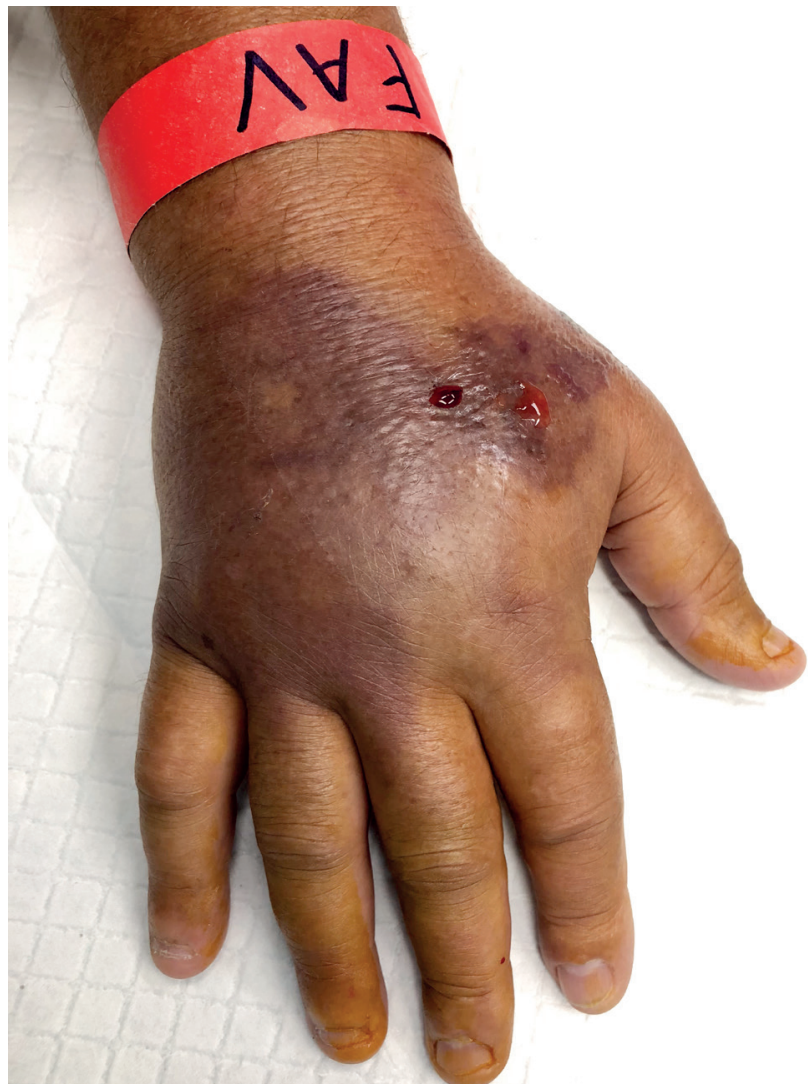

Figure 1 - Clinical presentation at admission, 12 hours after injury

the hand and forearm were skin grafted (Fig. 4). The patient was discharged from the hospital 70 days after admission after a total of six surgical interventions. A splint holding the wrist in extension was applied after ADM application until two weeks after skin graft. Daily physiotherapy was maintained for the next three months, and three times per week during the following six months. The patient was able to resume his daily life activities without restrictions. At present, he has a decreased amplitude of wrist and finger flexion (Fig. 5), but no extension restrictions.

\section{DISCUSSION}

Necrotizing fasciitis frequently appears only as lowgrade cellulitis and can be very challenging to make an early diagnosis. The most common examination findings at the time of presentation are warmth (97\%), erythema $(95 \%$ - $100 \%)$, edema $(82 \%)$ and disproportionate pain $(98 \%$ $100 \%) .{ }^{1,3}$ Patients are frequently hemodynamically unstable with elevated WBC counts, coagulopathy, and shock. ${ }^{4}$ Skin necrosis, bullae, crepitus, gas on imaging studies and hemodynamic instability, all suggestive signs of necrotizing fasciitis, are not always present. In fact one or more of these signs are present less than $50 \%$ of the time. ${ }^{5}$ A more specific sign is a gray fat and liquified pus with 'dishwater' appearance along the fascial planes during debridement, while frank pus is uncommon. ${ }^{6}$

Laboratory markers can aid in diagnosis, sodium levels below $135 \mathrm{mmol} / \mathrm{L}$ and WBC greater than $15400 \mathrm{cells} / \mu \mathrm{L}$ are the best predictors of necrotizing soft tissue infections. ${ }^{5}$ The Laboratory Risk Indicator for Necrotizing Fasciitis (LRINEC) scale was developed in an attempt to help in the diagnosis. ${ }^{7,8} \mathrm{~A}$ formal diagnosis of necrotizing fasciitis can be made on microscopic examination of biopsied fascia. ${ }^{9}$

An intensive care unit is recommended. Planned, staged debridements every 24 to 48 hours of affected limbs are expected, with an average of $3-4$ debridements per patient. ${ }^{1,10,11}$ Antibiotic therapy should be initiated empirically until retrieval of culture test results. The empirical antibiotic treatment should be broad (e.g, vancomycin or linezolid plus piperacillin-tazobactam or a carbapenem; or plus ceftriaxone and metronidazole), as the etiology can be polymicrobial. ${ }^{12}$ Mortality from necrotizing fasciitis usually ranges from $23 \%$ to $76 \%$, with organ failure and sepsis consisting in the major causes of death. ${ }^{13}$ The factors mostly associated with increased mortality are delay in diagnosis, delay in surgical debridement, advanced age and having two or more comorbilities. ${ }^{1}$

In 1981 an 'unnamed marine Vibrio' was isolated as the

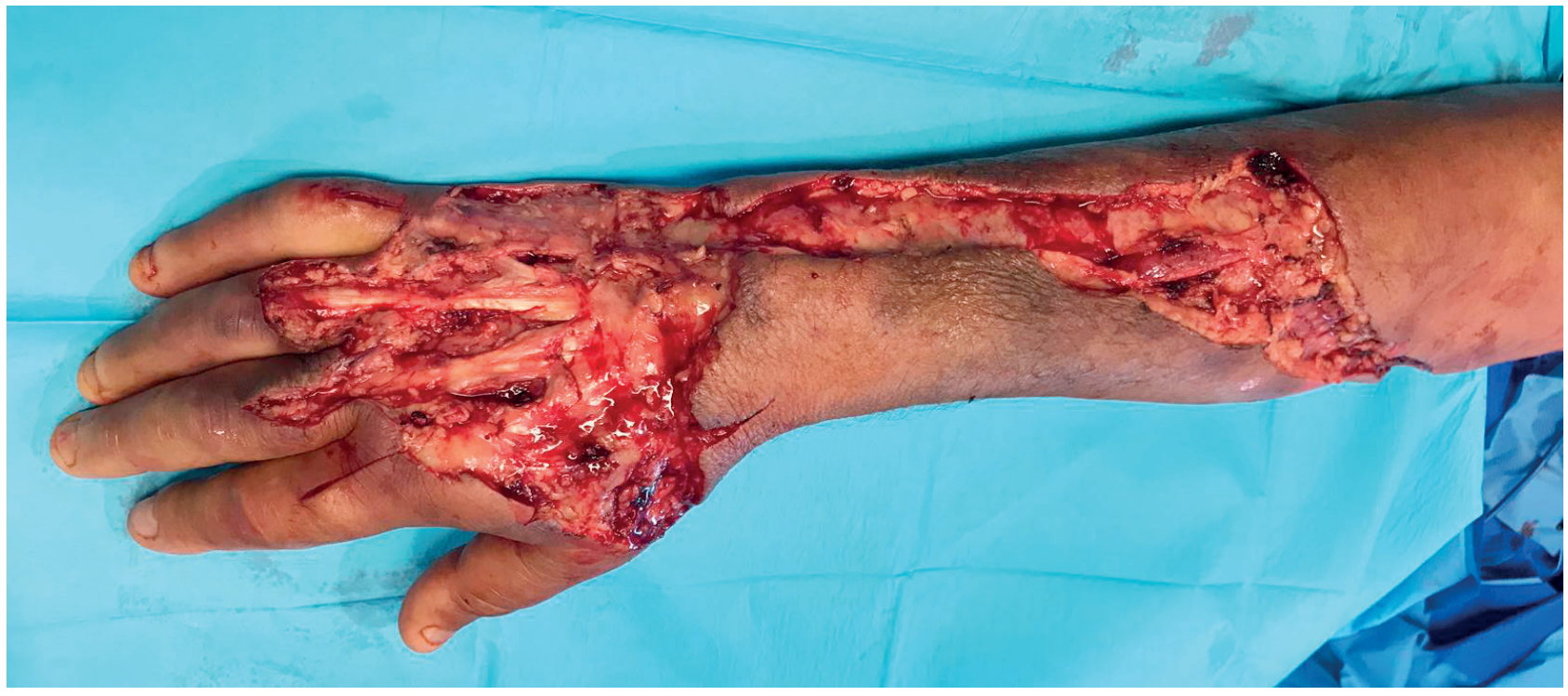

Figure 2 - Presentation after debridement 


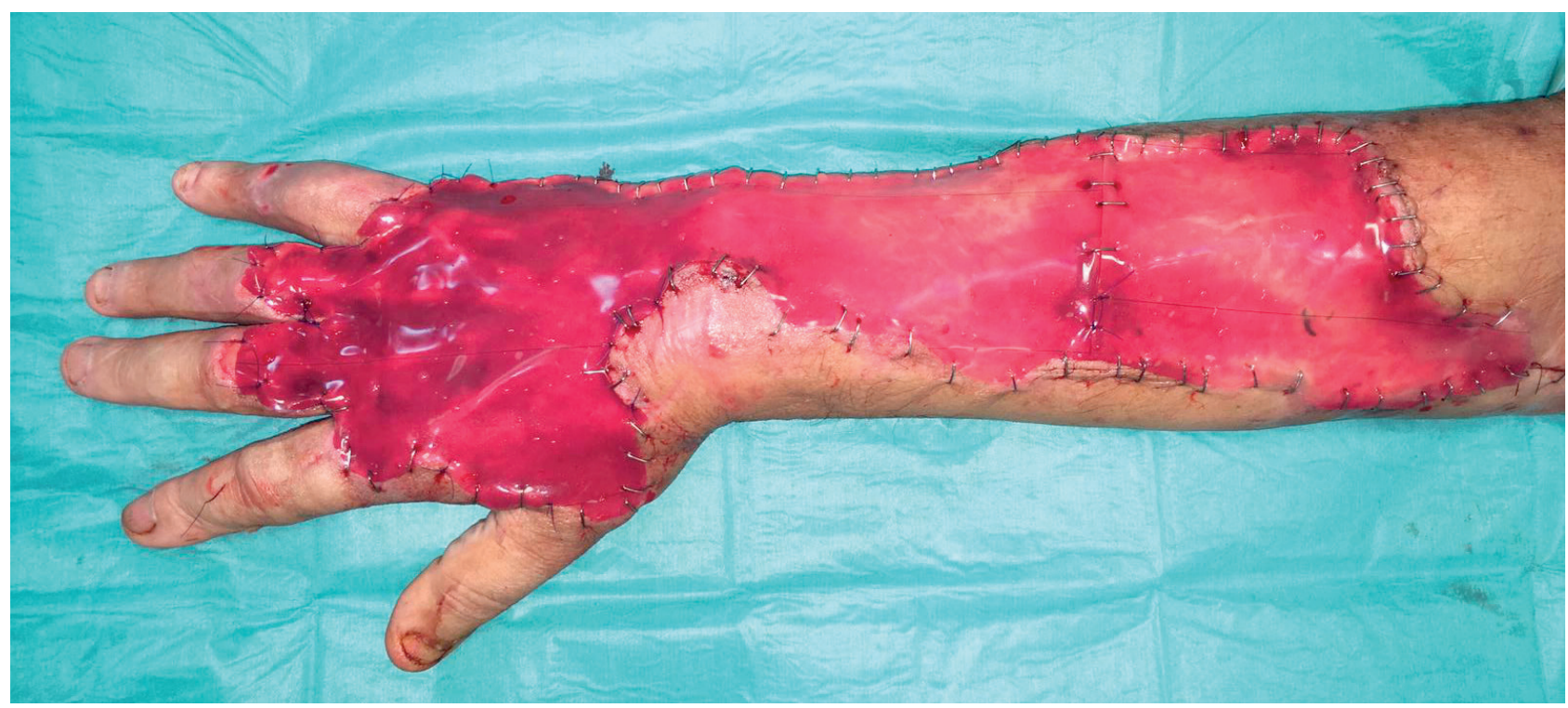

Figure 3 - Presentation after reconstruction with acellular dermal matrix

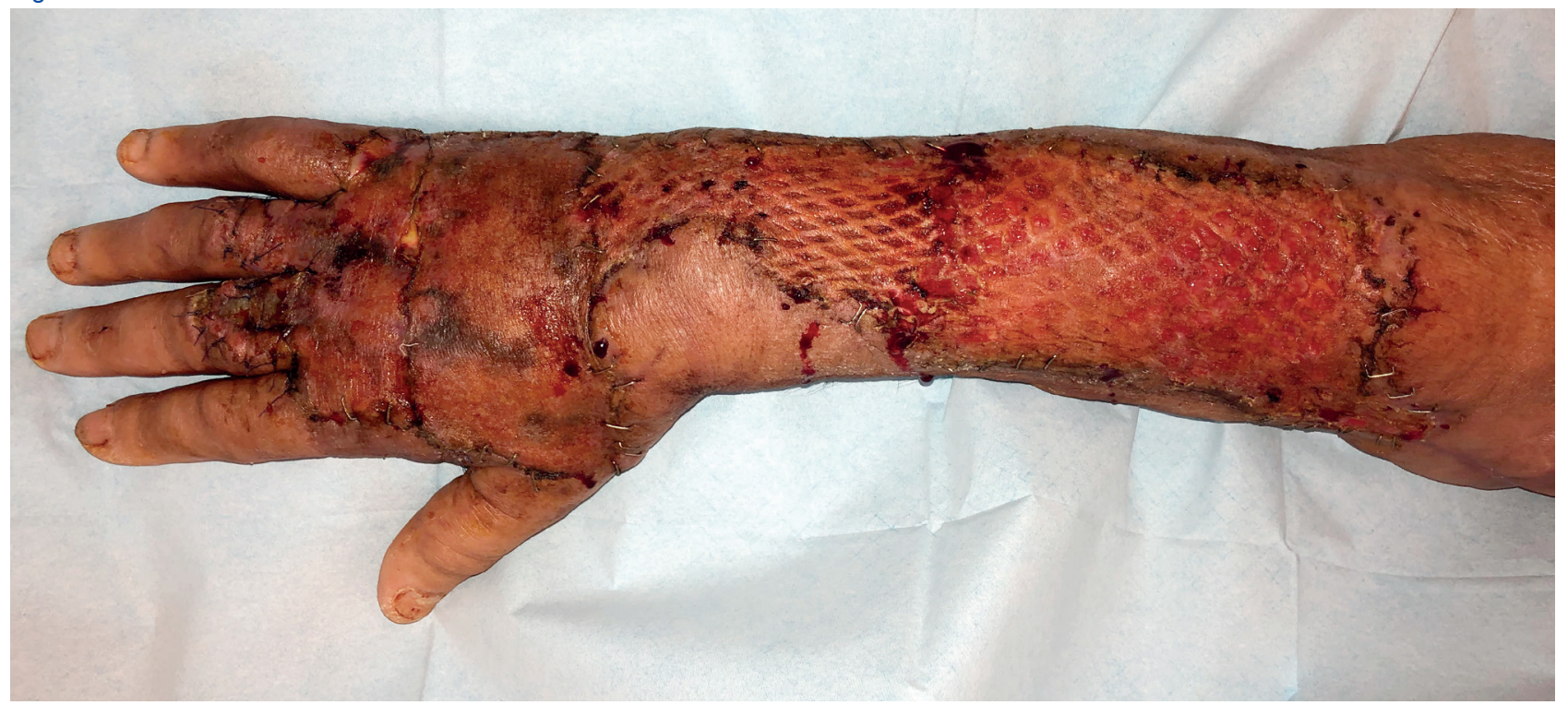

Figure 4 - Two months post-op

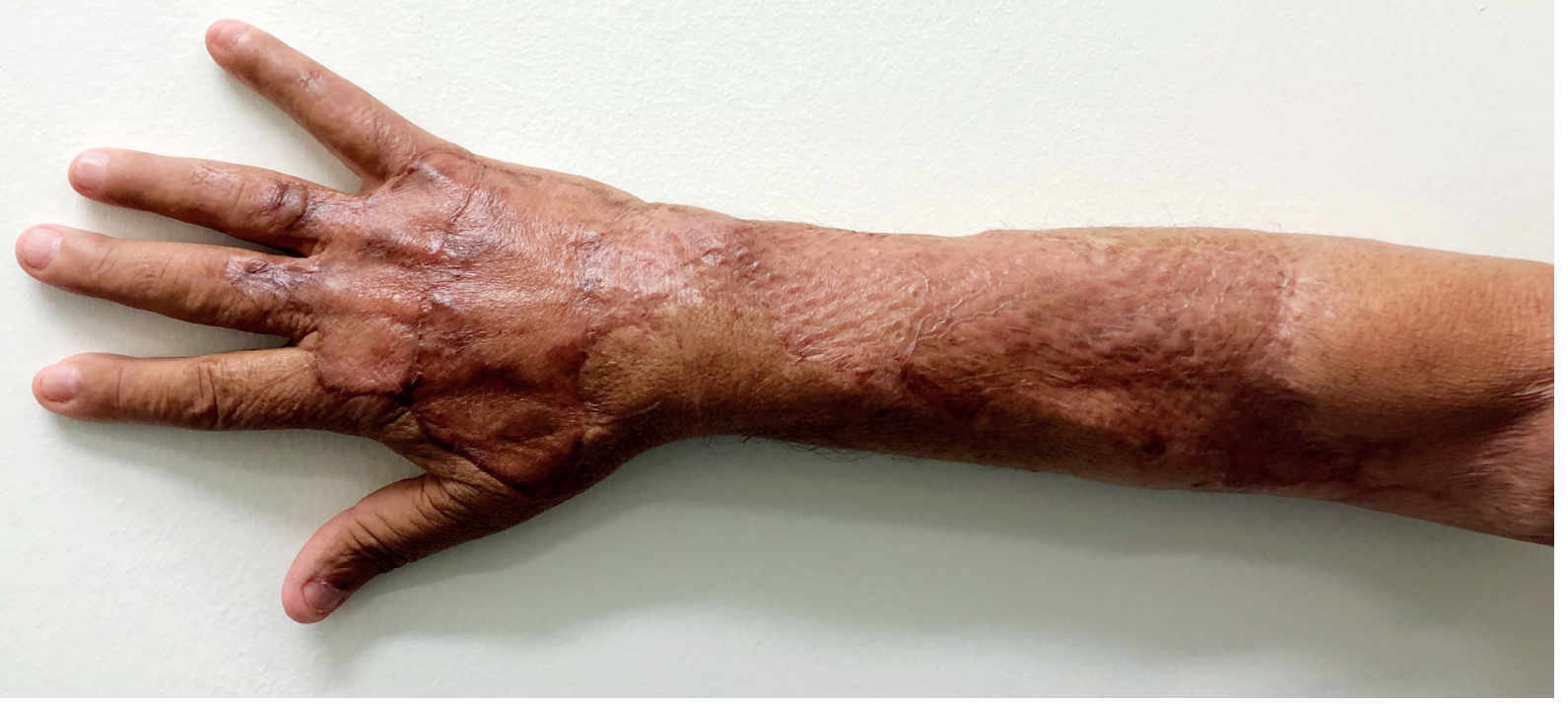

Figure 5 - Six months post-op 
causative agent of a human infectious case, ${ }^{14}$ posteriorly identified as $P$. damselae. A review of the soft tissue infections caused by this agent was made by Hundenborn et $a l^{15}$ in 2013, reporting 11 infection cases. In the 11 cases reported, eight $(73 \%)$ had a fatal outcome. In the three patients who could be cured, one required an amputation of the arm. When a search with the terms 'photobacterium damselae OR vibrio damselae' was carried out on the PubMed database and only case reports were selected, we retrieved 27 results, of which only 14 are skin or soft tissue infections in human. Most cases occurred in coastal areas of the United States of America, Australia, and Japan.

Other possible reconstructive options could be: a pedicle flap from another distal region (e.g. extended groin flap) with more complications expected; or a free flap (e.g. antero-lateral thigh) with important risks considering the A-V fistula in this arm, a possible blood steal syndrome in a patient on blood dialysis and anticoagulated. A skin graft without ADM was not possible because tendons did not have peritenon and there were no consistent local flaps available.

Necrotizing fasciitis is a rare infection that requires emergent surgery. A high degree of suspicious is necessary since delay in diagnosis can lead to loss of life or limb.

\section{AUTHORS CONTRIBUTION}

DG: Draft of the "Introduction" section.

\section{REFERENCES}

1. Wong $\mathrm{CH}$, Chang $\mathrm{HC}$, Pasupathy S, Khin LW, Tan JL, Low CO. Necrotizing fasciitis: clinical presentation, microbiology, and determinants of mortality. J Bone Joint Surg Am. 2003;85:1454-60.

2. Love M, Teebken-Fisher D, Hose JE, Farmer JJ, Hickman FW, Fanning GR. Vibrio damsela, a marine bacterium, causes skin ulcers on the damselfish chromis punctipinnis. Science. 1981;214:1139-40.

3. Childers BJ, Potyondy LD, Nachreiner R, Rogers FR, Childers ER, Oberg KC, et al. Necrotizing fasciitis: a fourteen-year retrospective study of 163 consecutive patients. Am Surg. 2002;68:109-16.

4. Koshy JC, Bell B. Hand infections. J Hand Surg Am. 2019;44:46-54.

5. Chan T, Yaghoubian A, Rosing D, Kaji A, de Virgilio C. Low sensitivity of physical examination findings in necrotizing soft tissue infection is improved with laboratory values: a prospective study. Am J Surg. 2008;196:926-30.

6. Gonzalez MH. Necrotizing fasciitis and gangrene of the upper extremity. Hand Clin. 1998;14:635-45.

7. Wong $\mathrm{CH}$, Khin LW, Heng $\mathrm{KS}$, Tan $\mathrm{KC}$, Low CO. The LRINEC (Laboratory Risk Indicator for Necrotizing Fasciitis) score: a tool for distinguishing necrotizing fasciitis from other soft tissue infections. Crit Care Med. 2004;32:1535-41.

8. Tsai $\mathrm{YH}$, Hsu RW, Huang KC, Huang TJ. Laboratory indicators for early detection and surgical treatment of vibrio necrotizing fasciitis. Clin Orthop Relat Res. 2010;468:2230-7.
LR: Draft of the "Case report" section.

LV: Draft of the "Discussion" section.

$\mathrm{RC}$ : Critical review of the paper.

\section{PROTECTION OF HUMANS AND ANIMALS}

The authors declare that the procedures were followed according to the regulations established by the Clinical $\mathrm{Re}$ search and Ethics Committee and to the Helsinki Declaration of the World Medical Association.

\section{DATA CONFIDENTIALITY}

The authors declare having followed the protocols in use at their working center regarding patients' data publication.

\section{INFORMED CONSENT}

Obtained.

\section{CONFLICTS OF INTEREST}

All authors report no conflict of interest.

\section{FUNDING SOURCES}

The authors declare that there were no external sources of study for the performance of this article.

9. Chauhan A, Wigton MD, Palmer BA. Necrotizing fasciitis. J Hand Surg Am. 2014;39:1598-601.

10. Angoules AG, Kontakis G, Drakoulakis E, Vrentzos G, Granick MS, Giannoudis PV. Necrotising fasciitis of upper and lower limb: a systematic review. Injury. 2007;38:S18-25.

11. Elliott DC, Kufera JA, Myers RA. Necrotizing soft tissue infections. Risk factors for mortality and strategies for management. Ann Surg. 1996;224:672-83

12. Stevens DL, Bisno AL, Chambers HF, Dellinger EP, Goldstein EJ, Gorbach SL, et al. Executive summary: practice guidelines for the diagnosis and management of skin and soft tissue infections: 2014 update by the Infectious Diseases Society of America. Clin Infect Dis. 2014;59:147-59.

13. Fontes RA, Ogilvie CM, Miclau T. Necrotizing soft-tissue infections. J Am Acad Orthop Surg. 2000;8:151-8

14. Morris JG, Miller HG, Wilson R, Tacket CO, Hollis DG, Hickman FW et al. Illness caused by vibrio damsela and vibrio hollisae. Lancet. 1982;1:1294-7.

15. Hundenborn J, Thurig S, Kommerell M, Haag H, Nolte O. Severe wound infection with photobacterium damselae ssp. damselae and vibrio harveyi, following a laceration injury in marine environment: a case report and review of the literature. Case Rep Med. 2013;2013:610632. 